Reviu Akuntansi dan Bisnis Indonesia, Vol. 5 No. 1, Hlm: 1-12, Juli 2021

Website: http://journal.umy.ac.id/index.php/rab

\title{
Faktor-faktor yang Mempengaruhi Auditor Switching
}

Deliana*; Abdul Rahman; Lifian Monica

Program Studi Akuntansi Keuangan Publik Politeknik Negeri Medan

I N F O A R T I K E L

Kata Kunci:

Auditor Switching; Opini

Audit; Pergantian

Manajemen; Financial

Distress

Jenis Artikel:

Penelitian Empiris

Korespondensi:

delianatar@gmail.com

Proses Artikel:

Diterima 12 Februari 2021

Review 13 Maret 2021

Review 9 April 2021

Revisi 22 April 2021

Diterbitkan 1 Juli 2021

Sitasi:

Deliana, D., Rahman, A., \&

Monica, L. (2021). Faktor-

Faktor yang Mempengaruhi

Auditor Switching. Reviu

Akuntansi dan Bisnis

Indonesia, 5(1), 1-12.

Link Artikel:

10.18196/rabin.v5i1.11136

\section{A B S T R A K}

\section{Latar Belakang:}

Pentingnya sikap independensi bagi seorang auditor dalam melakukan penugasan audit membuat setiap perusahaan harus melakukan auditor switching agar tingkat independensi dapat terjaga, namun pada kenyataannya sekalipun auditor switching telah dilakukan masih saja didapati auditor yang tidak menjaga sikap independensi. Hal ini menjadi menarik perhatian untuk diteliti mengenai hal apa saja yang menjadi faktor dalam melakukan auditor switching.

\section{Tujuan:}

Penelitian ini bertujuan untuk menguji pengaruh opini audit, pergantian manajemen dan financial distress terhadap auditor switching pada perusahaan manufaktur sub sektor real estate dan property yang terdaftar di Bursa Efek Indonesia periode 2016-2018.

\section{Metode Penelitian:}

Teknik sampling dalam penelitian ini adalah metode purposive sampling. Berdasarkan metode purposive sampling, sampel yang diperoleh sebanyak 43 perusahaan selama 3 tahun pengamatan dan total data observasi sebanyak 129 data. Metode analisis yang digunakan adalah analisis regresi logistik.

\section{Hasil Penelitian:}

Hasil penelitian menunjukkan bahwa variabel independen yaitu opini audit, pergantian manajemen, dan financial distress tidak berpengaruh terhadap auditor switching pada perusahaan manufaktur sub sektor real estate dan property yang terdaftar di Bursa Efek Indonesia periode 2016 - 2018.

\section{Keterbatasan Penelitian:}

Penelitian ini hanya meneliti perusahaan manufaktur sub sektor real estate dan property yang terdaftar di Bursa Efek Indonesia tahun 2016-2018, dan hanya menggunakan variabel opini audit, pergantian manajemen financial distress sebagai variabel yang mempengaruhi auditor switching.

\section{Keaslian/Novetly Penelitian:}

Penelitian ini menjawab gap penelitian terdahulu, dengan menggunakan variabel yang berbeda dari peneliti terdahulu dan rentang waktu yang berbeda dari tahun-tahun sebelumnya.

(C) 2021 RAB. Published by Universitas Muhammadiyah Yogyakarta DOI: $10.18196 /$ rabin.v5i1.11136 


\section{PENDAHULUAN}

Auditor dalam sebuah perusahaan khususnya perusahaan go-public, memiliki peranan yang sangat penting untuk melakukan pemeriksaan terhadap laporan keuangan yang telah dibuat oleh perusahaan. Perkembangan perusahaan go-public yang semakin berkembang pesat, akan berpengaruh pada auditor atau Kantor Akuntan Publik, hal ini karena perusahaan go-public membutuhkan perannya dalam memberikan jasa audit khususnya dalam laporan keuangan yang akan dipublikasikan. Beberapa tahun terakhir mulai dari tahun 2016 hingga tahun 2018 perusahaan go-public mengalami kenaikan yang signifikan seperti yang tercatat pada website Bursa Efek Indonesia.

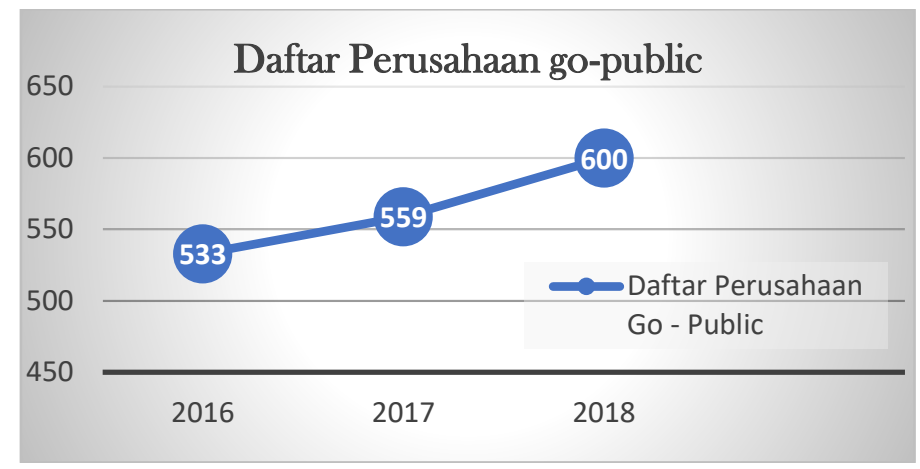

Gambar 1 Perkembangan Perusahaan go-public di Indonesia Sumber: Fact Book Bursa Efek Indonesia

Perusahaan yang telah menjadi go-public memiliki kewajiban untuk mempublikasikan laporan keuangan, sehingga setiap pihak-pihak yang terkait dengan perusahaan dapat mengetahui perkembangan yang terjadi. Pemeriksaan laporan keuangan harus dilakukan oleh pihak yang independen membuat permintaan akan jasa audit semakin meningkat seiring dengan pertumbuhan perusahaan go-public yang semakin berkembang pesat. Pertumbuhan Kantor Akuntan Publik yang begitu meningkat, hingga pada tanggal 2 Maret 2020 Kementerian Keuangan Republik Indonesia bagian Pusat Pembinaan Profesi Keuangan mempublikasikan jumlah dari Kantor Akuntan Publik yang aktif di Indonesia mencapai 473 Kantor Akuntan Publik. Dalam mempertahankan keandalan suatu laporan keuangan perusahaan dan independensi auditor maka perusahaan diwajibkan untuk melakukan auditor switching (Putra \& Suryanawa, 2016).

Auditor switching di Indonesia juga sangat didukung oleh pemerintah Indonesia yaitu dalam Peraturan Pemerintah Republik Indonesia Nomor 20 Tahun 2015 dan Dalam memperketat pengawasan di bidang jasa audit, Otoritas Jasa Keuangan juga mengeluarkan Peraturan Otoritas Jasa Keuangan Nomor 13/ PJOK.03/2017 tentang Penggunaan Jasa Akuntan dan Kantor Akuntan Publik dalam Kegiatan Jasa Keuangan. Ketetapan peraturan tentang auditor switching yang telah disahkan oleh pemerintah Indonesia membuat setiap perusahaan khususnya perusahaan go-public harus melakukan auditor switching agar tingkat independensi auditor tetap terjaga sehingga tidak melanggar kode etik profesi dalam melaksanakan tugas audit, namun pada kenyataannya meskipun peraturan yang telah ditetapkan begitu ketat, perusahaan yang melakukan pelanggaran peraturan masih didapati.

Salah satu perusahaan ternama di Indonesia yaitu PT Garuda Indonesia yang baru saja melakukan pelanggaran dalam penyusunan laporan keuangan, sehingga PT Garuda Indonesia dikenakan sanksi dan Otoritas Jasa Keuangan meminta agar perusahaan tersebut melakukan auditor switching (Kompas.com, 2019). Selain itu, PT Asuransi Jiwasyara (Persero) di akhir 2019 juga terbukti bahwa laporan keuangan yang dipublikasikan oleh perusahaan tidak sesuai dengan kebenarannya, perusahaan tersebut juga sering melakukan auditor switching, setidaknya dari tahun 2006 - 2014 perusahaan tersebut melakukan auditor switching sebanyak empat kali, tetapi Kantor Akuntan Publik yang melakukan penugasan audit tersebut tidak dapat menemukan masalah 
tersebut (Berita Satu, 2019). Adanya fenomena tentang auditor switching membuat hal tersebut menjadi pembahasan yang sangat menarik untuk diteliti.

Ada beberapa faktor yang mempengaruhi perusahaan untuk melakukan auditor switching yaitu opini audit, pergantian manajemen dan financial distress. Pernyataan bahwa opini audit dapat mempengaruhi auditor switching didukung oleh Putra dan Suryanawa (2016); Permata Sari dan Astika (2018); Alisa, Devi, dan Brillyandra (2019), namun berbeda pendapat dengan Pawitri dan Yadnyana (2015); Heliodoro, Carreira, dan Lopes (2016), Kholipah dan Suryandari (2019); yang mengatakan bahwa opini audit tidak memiliki pengaruh bagi perusahaan dalam melakukan auditor switching. Pergantian manajemen merupakan salah satu faktor yang dapat mempengaruhi terjadinya auditor switching di suatu perusahaan. Penelitian yang mendukung pernyataan tersebut disampaikan oleh Pawitri dan Yadnyana (2015); Wea dan Murdiawati (2015); Manto dan Wanda (2018); Safriliana dan Muawanah (2019), namun juga terdapat beberapa peneliti yang menolak pernyataan tersebut seperti Karina, Kholmi, dan Harventy (2014); Kurniaty, Hasan, dan Anisma (2014): Augusty dan Wilopo (2017).

Financial distress mempengaruhi auditor switching, pernyataan ini didukung oleh Thahir Abdul Nasser dkk. (2006); Wea dan Murdiawati (2015); Adha dan Noch (2017), tetapi berbeda dengan peneliti lain yang menyatakan bahwa financial distress bukan faktor yang mempengaruhi terjadinya auditor switching, peneliti tersebut ialah Kurniaty dkk (2014); Augusty dan Wilopo (2017); Safriliana dan Muawanah (2019). Penelitian ini bertujuan untuk menganalisis dan memberikan bukti pengaruh opini audit (audit opinion), pergantian manajemen (management change) dan kesulitan keuangan (financial distress) terhadap terjadinya auditor switching: Perbedaan penelitian ini dengan penelitian terdahulu adalah variabel independen dan rentang waktu yang digunakan. Variabel independen yang digunakan dalam penelitian ini adalah opini audit, pergantian manajemen dan financial distress, sedangkan untuk periode waktunya dalam penelitian ini lebih terbaru dibandingkan dengan penelitian sebelumnya yaitu mulai dari tahun 2016 - 2018 dan data dalam penelitian ini menggunakan sampel yang berasal dari perusahaan manufaktur dengan sub sektor real estate dan property yang terdaftar di Bursa Efek Indonesia. Penelitian diharapkan dapat memberikan kontribusi pengembangan ilmu khususnya dalam bidang auditing dan akuntansi keuangan. Bagi profesi akuntan publik penelitian ini diharapkan dapat memberikan tambahan informasi tentang faktor yang mempengaruhi auditor switching dan bagi pemerintah untuk mengevaluasi hal- hal yang berkaitan dengan auditor switching

\section{TINJAUAN LITERATUR DAN PERUMUSAN HIPOTESIS}

\section{Auditor Switching}

Auditor switching adalah suatu tindakan penting yang dilakukan oleh perusahaan klien untuk memutuskan beralih auditor atau kantor akuntan publik dalam hal melakukan penugasan audit bagi perusahaan dengan tujuan untuk meningkatkan independensi antara Kantor Akuntan Publik dengan perusahaan klien. Secara umum ada dua jenis auditor switching yakni auditor switching yang bersifat wajib (mandatory) dan auditor switching yang bersifat sukarela (voluntary).

Auditor switching bersifat mandatory adalah pergantian auditor yang terjadi karena adanya regulasi atau peraturan yang mewajibkan perusahaan untuk melakukan rotasi kantor akuntan publik (Wea dan Murdiawati, 2015). Auditor switching yang bersifat voluntary berarti pergantian auditor yang dilakukan karena adanya suatu unsur - unsur tertentu dari perusahaan klien maupun kantor akuntan publik yang di luar dari ketentuan peraturan yang berlaku (Pawitri \& Yadnyana, 2015).

\section{Pengaruh Opini Audit terhadap Auditor Switching}

Opini audit dari seorang auditor merupakan hal yang sangat penting bagi perusahaan untuk meningkatkan tingkat kepercayaan para stakeholders. Pentingnya opini wajar tanpa pengecualian dari seorang auditor membuat pihak manajemen berusaha untuk mendapatkan opini tersebut agar mencapai tujuan yang mereka inginkan. Apabila perusahaan mendapatkan opini audit atas laporan keuangan yang tidak sesuai dengan keinginan manajemen, maka manajemen cenderung untuk 
melakukan auditor switching terhadap perusahaan tersebut (Putra \& Suryanawa, 2016), namun sebaliknya ketika perusahaan telah menerima opini wajar tanpa pengecualian yang identik dengan keinginan manajemen serta mereka merasa puas atas pendapat tersebut, maka pihak manajemen merasa tidak perlu melakukan auditor switching pada perusahaan (Wea dan Murdiawati, 2015).

Hal ini menunjukkan bahwa adanya pengaruh dari opini audit untuk sebuah perusahaan memutuskan melakukan auditor switching. Pernyataan tersebut di dukung oleh para peneliti sebelumnya yaitu Putra dan Suryanawa (2016); Permata Sari dan Astika (2018); Alis dkk. (2019). Semakin banyak perusahaan menerima opini audit yang tidak berkualitas, semakin ia merasa tidak cukup puas dan akhirnya mendorong manajemen untuk melakukan auditor switching (Kusuma dan Farida 2019).

\section{$\boldsymbol{H}_{1:}$ Opini Audit berpengaruh terhadap auditor switching.}

\section{Pengaruh Pergantian Manajemen terhadap Auditor Switching}

Pergantian manajemen yang dilakukan oleh perusahaan akan berpengaruh bagi perusahaan, yang memungkinkan akan ada kebijakan baru ketika dilakukan pergantian manajemen. Salah satu kebijakan baru yang dapat dilakukan adalah melakukan auditor switching bagi perusahaan. Hal ini dapat terjadi karena manajemen baru akan lebih memilih untuk mencari KAP yang selaras dengan tujuannya dan manajemen yang baru cenderung lebih memilih kantor akuntan publik atau auditor yang memberi keleluasaan pada pihak manajemen yang berguna untuk memilih prosedur akuntansi yang menguntungkan bagi manajemen itu sendiri (Wea \& Murdiawati, 2015). Pihak manajemen berupaya dalam melakukan auditor switching untuk memperbaharui keyakinan para stakeholeders khususnya para pemegang saham dalam sistem pelaporan keuangan serta untuk mengisntal pemantauan yang lebih baik (Nazatul Faiza Syed Mustapha Nazri, Smith, \& Ismail, 2012).

Penelitian sebelumnya yang mendukung bahwa pergantian manajemen memiliki pengaruh terhadap auditor switching adalah Hudaib dan Cooke (2005); Nazatul Faiza Syed Mustapha Nazri dkk. (2012); Pawitri dan Yadnyana (2015); Manto dan Wanda (2018). Adanya motivasi yang diinginkan manajemen baru untuk memenuhi kebutuhan yang mereka inginkan akan mempengaruhi terjadinya auditor switching di perusahaan tersebut (Chadegani, Mohamed, \& Jari, 2011).

\section{$\boldsymbol{H}_{2}$ : Pergantian Manajemen berpengaruh terhadap auditor switching.}

\section{Pengaruh Financial Distress terhadap Auditor Switching}

Financial distress yang terjadi pada sebuah entitas menggambarkan bahwa kondisi keuangan perusahaan sedang tidak sehat. Alasan kondisi keuangan yang tidak sehat menjadi salah satu faktor yang mempengaruhi perusahaan untuk melakukan auditor switching (Augusty \& Wilopo, 2017). Kondisi perusahaan akan lebih buruk jika biaya tambahan lebih banyak terjadi di perusahaan seperti biaya keuangan yang mahal, biaya peluang proyek dan karyawan yang kurang produktif, hal tersebut juga akan membuat kemampuan perusahaan akan semakin berkurang, sehingga perusahaan akan lebih memilih untuk melakukan auditor switching yang sesuai dengan kemampuan mereka (Kusuma dan Farida, 2019).

Financial distress merupakan faktor pendorong yang mempengaruhi perusahaan untuk melakukan auditor switching, hal ini karena semakin tingginya biaya audit yang dibebankan kepada perusahaan yang sedang mengalami financial distress maka membuat perusahaan tersebut untuk melakukan auditor switching dengan memilih kantor akuntan publik yang memberikan pelayanan audit dengan biaya yang tidak terlalu tinggi (Wea dan Murdiawati, 2015). Financial distress berpengaruh pada auditor switching, pernyataan ini didukung oleh para peneliti yang sebelumnya yaitu Thahir Abdul Nasser dkk. (2006); Wea dan Murdiawati (2015); Adha dan Noch (2017);, Kusuma dan Farida (2019). Perusahaan yang mengalami financial distress akan memiliki dorongan yang kuat untuk melakukan auditor switching (Kurniaty dkk., 2014). 
$\boldsymbol{H}_{3:}$ Financial Distress berpengaruh terhadap auditor switching.

Berdasarkan uraian pengembangan hipotesis, maka kerangka berpikir dalam penelitian ini dapat di gambarkan dalam kerangka konseptual:

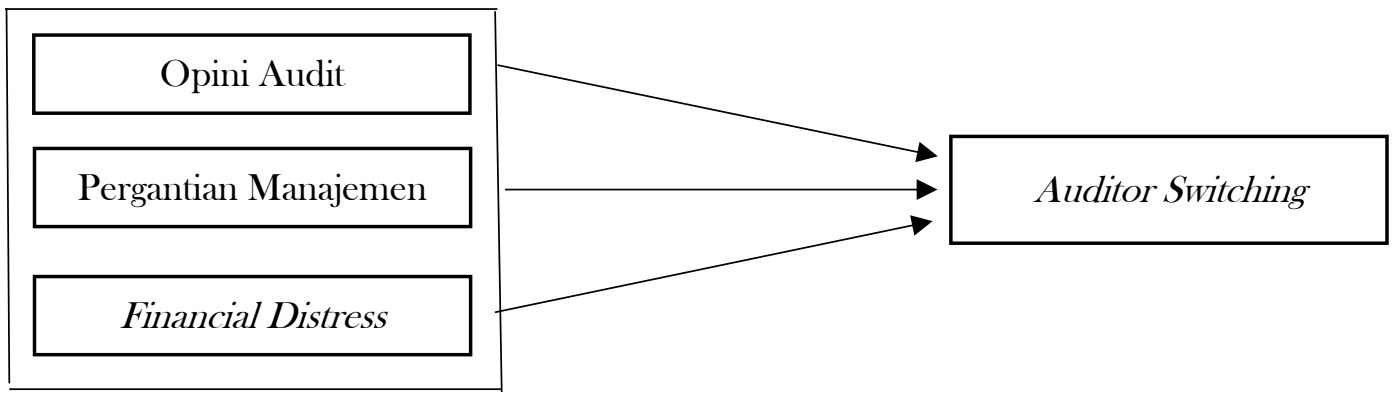

Gambar 2 Kerangka Konseptual

\section{METODE PENELITIAN}

\section{Objek Penelitian}

Objek dalam penelitian ini adalah faktor-faktor yang mempengaruhi auditor switching yaitu opini audit, pergantian manajemen dan financial distress pada perusahaan manufaktur sub sektor real estate dan property yang terdaftar di Bursa Efek Indonesia.

\section{Operasionalisasi Variabel}

Variabel dependen dalam penelitian ini adalah auditor switching. Variabel ini menggunakan variabel dummy (variabel kategorikal), apabila perusahaan klien melakukan auditor switching maka diberi nilai 1, dan jika perusahaan klien tidak melakukan auditor switching maka diberi nilai 0 (Thahir Abdul Nasser dkk. (2006); Lin dan Liu (2010); Augusty dan Wilopo (2017); Permata Sari dan Astika (208); Manto dan Wanda (2018)).Variabel independen dalam penelitian ini adalah opini audit, pergantian manajemen dan financial distress.

\section{Opini Audit}

Opini audit diproksikan dengan variabel dummy. Dalam penelitian ini opini audit di klasifikasikan menjadi dua bagian yaitu: Opini wajar tanpa pengeculian, apabila auditor memberikan pendapat bahwa laporan keuangan telah disajikan secara wajar sesuai dengan prinsip akuntansi yang berlaku umum, maka di beri nilai 1 . Opini selain wajar tanpa pengecualian, yaitu apabila auditor opini wajar tanpa pengecualian dengan kalimat penjelas, wajar dengan pengecualian, pendapat tidak wajar (adverse opinion), dan menolak memberikan pendapat (disclaimer), maka di beri nilai 0 . Penelitian terdahulu yang telah menggunakan pengukuran tersebut adalah Penelitian Lin dan Liu (2010); Chadegani dkk. (2011); Nazatul Faiza Syed Mustapha Nazri dkk. (2012); Pawitri dan Yadnyana (2015); Kholipah dan Suryandari (2019).

\section{Pergantian Manajemen}

Variabel pergantian manajemen diproksikan dengan variabel dummy. Jika Perusahaan melakukan perubahan pada dewan direksi, diberi nilai 1 dan jika perusahaan tidak mengganti dewan direksi maka diberi nilai 0 . Adapun penelitian terdahulu yang menggunakan variabel dummy sebagai proksi pergantian manajemen adalah penelitian Chadegani dkk. (2011); Nazatul Faiza Syed Mustapha Nazri dkk. (2012); Pawitri dan Yadnyana (2015); Augusty dan Wilopo (2017); Manto dan Wanda (2018). 


\section{Financial Disstress}

Dalam penelitian ini financial distress diproksikan dengan rasio DER (Debt to Equity Ratio), rumusnya adalah sebagai berikut:

$$
D E R=\frac{\text { Total Hutang }}{\text { Total Equity }} X 100 \%
$$

Penelitian terdahulu yang menggunakan pengukuran tersebut adalah Chadegani dkk. (2011); Kurtniaty, dkk (2014); Wea dan Murdiawati (2015); Putra dan Suryanawa (2016); Kusuma dan Farida (2019).

\section{Populasi dan Sampel}

Dalam penelitian ini yang menjadi populasi adalah seluruh perusahaan manufaktur sub sektor real estate dan property yang terdaftar di Bursa Efek Indonesia. Teknik pengambilan sampel dalam penelitian ini adalah purposive sampling. Berdasarkan kriteria sampel, total perusahaan yang memenuhi kriteria sejumlah 43 perusahaan. Jumlah periode pengamatan yang dilakukan dalam penelitian ini selama 3 tahun, maka jumlah data observasi yang digunakan dalam penelitian ini sebanyak 129 data.

\section{Jenis Data}

Jenis data yang digunakan dalam penelitian ini adalah data sekunder yaitu data primer yang telah diolah lebih lanjut oleh pihak lain atau pengumpul data yang dapat disajikan dalam bentuk tabel atau diagram (Sugiarto, 2017:202).

\section{Teknik Analisis Data}

Teknik analisis yang dilakukan dalam penelitian ini adalah teknik analisis kuantitatif. Metode analisis yang digunakan dalam penelitian ini adalah metode analisis regresi logistik.

1. Statistik Deskriptif

Analisis deskripsi bertujuan untuk memberikan deskripsi data variabel dependen dan variabel independen dalam penelitian ini.

2. Analisis Regresi Logistik

Analisis regresi logistik adalah analisis regresi yang di gunakan saat variabel dependennya mengambil bentuk dikotomi atau biner variabel $\mathrm{Y}$, yang dapat dikodekan dengan 1 atau 0 dan variabel independennya merupakan variabel kontinu, kategorikal atau keduanya (Sugiato, 2017:355). Adapun langkah- langkah dalam analisis regresi logistik adalah sebagai berikut:

a) Menilai Keseluruhan Model (Overal Model Fit)

b) Koefisien Determinasi (Nagelkerke $R$ Square)

c) Menguji Kelayakan Model Regresi

d) Pengujian Hipotesis

3. Model Regresi Logistik yang Terbentuk

Dalam penelitian ini menggunakan analisis regresi logistik, analisis ini dilakukan dengan melihat pengaruh opini audit, pergantian manajemen, financial distress terhadap auditor switching pada perusahaan manufaktur sub sub sektor real estate dan property yang terdaftar di Bursa Efek Indonesia. Berdasarkan pemaparan, maka model regresi logistik dalam penelitian ini dirumuskan sebagai berikut:

$$
\text { SWITCH }=\alpha+\beta 1 O P+\beta 2 P M+\beta 3 \text { FD }+\mathrm{e}
$$

Keterangan:

$\begin{array}{ll}\text { SWITCH } & : \text { Auditor } S_{\text {witching }} \\ \alpha & : \text { Konstanta } \\ \beta & : \text { Konstanta Regresi }\end{array}$




$\begin{array}{ll}\text { OP } & : \text { Opini Audit } \\ \text { PM } & : \text { Pergantian Manajemen } \\ \text { FD } & : \text { Financial Distress } \\ \text { e } & : \text { Eror }\end{array}$

\section{HASIL DAN PEMBAHASAN}

\section{Hasil Pengolahan Data}

\section{Statistik Deskriptif}

Berdasarkan Tabel 1, maka hasil analisis deskriptif menunjukkan bahwa auditor switching di perusahaan manufaktur sub sektor real estate dan property tidak terlalu sering dilakukan dan opini audit yang didapatkan oleh perusahaan sebagian besar adalah opini wajar tanpa pengecualian. Dari Tabel 1 juga menggambarkan bahwa pergantian manajemen lebih sedikit dilakukan oleh perusahaan manufaktur sub sektor real estate dan property, sementara itu untuk hasil financial distress menjelaskan bahwa financial distress lebih banyak terjadi di perusahaan manufaktur sub sektor real estate dan property.

Tabel 1 Statistik Deskriptif

\begin{tabular}{lrrrrr}
\hline & \multicolumn{5}{c}{ Descriptive Statistics } \\
& Minimum & Maximum & Mean & Std. Deviation \\
\hline Opini Audit & 129 & 0 & 1 & .99 & .088 \\
Pergantian Manajemen & 129 & 0 & 1 & .43 & .496 \\
Financial Distress & 129 & .04 & 3.70 & .7802 & .68584 \\
Auditor Switching & 129 & 0 & 1 & .45 & .499 \\
Valid N (listwise) & 129 & & & & \\
\hline
\end{tabular}

\section{Hasil Uji Hipotesis}

Metode analisis yang digunakan dalam penelitian ini adalah metode analisis regresi logistik. Dalam metode analisis regresi logistik tidak menggunakan uji asumsi klasik. Alasan menggunakan metode analisis regresi logistik adalah variabel dependen dalam penelitian ini bersifat dikotomi yaitu variabel yang memiliki dua nilai kategori (Kholipah \& Suryandari, 2019) dan merupakan suatu tindakan melakukan atau tidak melakukan (Wea \& Murdiawati 2015). Selain itu variabel dependen dalam penelitian ini merupakan data non metrik, sedangkan variabel independen merupakan campuran antara variabel kontinu (data metrik) dan katagorikal yang merupakan data nonmetirik (Manto \& Wanda (2018); Putra \& I ketut (2016)). Adapun tahapan dalam proses pengujian hipotesis adalah sebagai berikut:

\section{1) Menilai Keseluruhan Model (Overal Model Fit)}

Menilai model keseluruhan model digunakan untuk mengetahui model fit dengan data. Hipotesis untuk menilai model fit adalah:

$\mathrm{H}_{0} \quad$ : Model dihipotesiskan fit dengan data

$\mathrm{H}_{\mathrm{a}} \quad$ : Model yang dihipotesiskan tidak fit dengan data

Hal ini berarti $\mathrm{H}_{0}$ harus diterima agar model fit dengan data (Ghozali, 2018). Pengujian dalam model ini dilakukan dengan cara membandingkan nilai antara -2 $\log$ likehood (-2LL) yang awal (block number $=0$ ) dengan -2 log likehood (-2LL) yang akhir (block number=1). Apabila dalam hasil pengujian terdapat penurunan nilai antara -2 LL (Block Number=0) yang awal dengan -2LL yang akhir (Block Number=1) maka menunjukkan bahwa model yang dihipotesiskan fit dengan data. Penurunan nilai Log Likehood menjelaskan bahwa model regresi yang digunakan semakin baik. 
Tabel 2 Hasil Uji Fit 1 (Block 0: Beginning Block)

\begin{tabular}{cccc}
\hline & \multicolumn{1}{c}{$\begin{array}{c}\text { Iteration History a,b,c } \\
\text { Iteration }\end{array}$} & -2 Log likelihood & Coefficients Constant \\
\hline Step 0 & 1 & 177,520 & $-0,202$ \\
& 2 & 177,520 & $-0,202$ \\
\hline
\end{tabular}

Tabel 3 Uji Fit 2 (Block 1: Method= Enter )

\begin{tabular}{|c|c|c|c|c|c|c|}
\hline \multicolumn{7}{|c|}{ Iteration History a,b,c,d } \\
\hline \multirow[t]{2}{*}{ Iteration } & & \multirow{2}{*}{$\begin{array}{c}-2 \log \\
\text { likelihood }\end{array}$} & \multicolumn{4}{|c|}{ Coefficients } \\
\hline & & & Constant & Opini & Pergantian & $\begin{array}{l}\text { Financial } \\
\text { Distress }\end{array}$ \\
\hline \multirow[t]{20}{*}{ Step 1} & 1 & 175,609 & 2,250 & $-2,380$ & $-0,262$ & 0,027 \\
\hline & 2 & 175,440 & 3,390 & $-3,520$ & $-0,266$ & 0,028 \\
\hline & 3 & 175,386 & 4,433 & $-4,564$ & $-0,266$ & 0,028 \\
\hline & 4 & 175,366 & 5,449 & $-5,579$ & $-0,266$ & 0,028 \\
\hline & 5 & 175,359 & 6,454 & $-6,584$ & $-0,266$ & 0,028 \\
\hline & 6 & 175357 & 7,456 & $-7,586$ & $-0,266$ & 0,028 \\
\hline & 7 & 175,356 & 8,457 & $-8,587$ & $-0,266$ & 0,028 \\
\hline & 8 & 175,355 & 9,457 & $-9,587$ & $-0,266$ & 0,028 \\
\hline & 9 & 175,355 & 10,457 & $-10,588$ & $-0,266$ & 0,028 \\
\hline & 10 & 175,355 & 11,457 & $-11,588$ & $-0,266$ & 0,028 \\
\hline & 11 & 175,355 & 12,457 & $-12,588$ & $-0,266$ & 0,028 \\
\hline & 12 & 175,355 & 13,457 & $-13,588$ & $-0,266$ & 0,028 \\
\hline & 13 & 175,355 & 14,457 & $-14,588$ & $-0,266$ & 0,028 \\
\hline & 14 & 175,355 & 15,457 & -15588 & $-0,266$ & 0,028 \\
\hline & 15 & 175,355 & 16,457 & $-16,588$ & $-0,266$ & 0,028 \\
\hline & 16 & 175,355 & 17,457 & $-17,588$ & $-0,266$ & 0,028 \\
\hline & 17 & 175,355 & 18,457 & $-18,588$ & $-0,266$ & 0,028 \\
\hline & 18 & 175,355 & 19,457 & $-19,588$ & $-0,266$ & 0,028 \\
\hline & 19 & 175,355 & 20,457 & $-20,588$ & $-0,266$ & 0,028 \\
\hline & 20 & 175,355 & 21,457 & $-21,588$ & $-0,266$ & 0,028 \\
\hline
\end{tabular}

Berdasarkan Tabel 2 dan Tabel 3 terlihat bahwa terjadi penurunan nilai -2 LL pada tahap awal (Block Number $=0)$ sebesar 177,52 dan pada tahap akhir (Block Number $=1$ ) memiliki nilai 175,355. Hal tersebut memiliki arti bahwa model fit dengan data karena terjadi penurunan nilai dari blok pertama ke blok kedua.

\section{2) Menguji Kelayakan Regresi}

Tahapan kedua dari analisis regresi logistik adalah menguji kelayakan regresi. Pengujian kelayakan dengan menggunakan Goodness of Fit Test. Apabila nilai statistik Hosmer and Lemeshow Goodness of Fit Test lebih besar dari pada 0,05 maka hipotesis nol dapat diterima dan memiliki arti bahwa model mampu memprediksi nilai observasinya (Ghozali, 2018). Hasil statistik Hosmer and Lemeshow Goodness of Fit Test terdapat pada Tabel 4.

Tabel 4. Hasil Hosmer and Lemeshow Goodness Of Fit Test

\begin{tabular}{cccc}
\hline & Hosmer and Lemeshow Test & \\
Step & Chi-square & $d f$ & Sig. \\
1 & 4.996 & 8 & 0,758 \\
\hline
\end{tabular}

Berdasarkan Tabel 4, hasil menunjukkan bahwa pengujian Hosmer and Lemeshow Goodness of Fit Test diperoleh Chi - square sebesar 4,996 dengan nilai signifikansi sebesar 0,758 dan df8. Hasil tersebut memperlihatkan bahwa nilai signifikasi lebih besar dari 0,05 sehingga $\mathrm{H}_{0}$ diterima 
dan hal tersebut berarti model yang digunakan mampu memprediksi nilai observasinya dan model regresi layak digunakan pada tahap analisis selanjutnya.

\section{3) Kofisien Determinasi (Nagelkerke's R2)}

Tahapan analisis selanjutnya adalah uji koefisien determinasi (Nagelkerke's R2). Pengujian koefisien determinasi dilakukan untuk mengetahui seberapa besar variabel independen yaitu opini audit, pergantian manajemen dan financial distress mampu menjelaskan variabel dependen yaitu auditor switching. Koefisien determinasi pada regresi logistik dapat dilihat dari nilai Negelkerke $R$ Square. Hasil dari koefisien determinasi dapat dilihat pada Tabel 5.

Tabel 5 Uji Kofisien Determinasi

\begin{tabular}{cccc}
\hline & Model Summary \\
Step & -2 Log likelihood & Cox \& Snell R Square & Nagelkerke R Square \\
\hline 1 & $175.355 \mathrm{a}$ & .017 & 0,022 \\
\hline
\end{tabular}

Tabel 5 menjelaskan bahwa nilai Negelkerke $\boldsymbol{R}$ Square sebesar 0,022 (2,2\%) dan nilai Cox \& Snell $R$ Square 0,98 (98\%). Hal ini menujukan bahwa variabel independen yaitu opini audit, pergantian manajemen dan financial distress mampu menjelaskan variabel dependen yaitu auditor switching sebesar 2,2\%, sementara sisanya dijelaskan oleh faktor-faktor lain di luar model penelitian.

\section{4) Menguji Koefisien Regresi}

Menguji koefisien regresi merupakan tahapan terakhir dalam analisis regresi logistik. Uji koefisien regresi dapat dilakukan dengan melihat pada kolom variabels in the equation dan membandingkan kolom signifikan dengan tingkat kealpaan 0,05 (5\%). Apabila tingkat $<0,05$ maka $\mathrm{H}_{0}$ diterima.

Tabel 6 Uji Kofisien Regresi Variables in the Equation

\begin{tabular}{|c|c|c|c|c|c|c|c|}
\hline & & $\mathrm{B}$ & S.E. & Wald & $\mathrm{df}$ & Sig. & $\operatorname{Exp}(B)$ \\
\hline \multirow[t]{5}{*}{ Step 1a } & Opini Audit & $-21,588$ & 40193,222 & 0,000 & 1 & 1,000 & 0,000 \\
\hline & Pergantian & -.266 & 0,362 & 0,539 & 1 & 0,463 & 0,767 \\
\hline & Manajemen & & & & & & \\
\hline & $\begin{array}{l}\text { Financial } \\
\text { Distress }\end{array}$ & 0,028 & 0,260 & 0,011 & 1 & 0,915 & 1,028 \\
\hline & Constant & 21,457 & 40193,222 & 0,000 & 1 & 1,000 & 2083496984,307 \\
\hline
\end{tabular}

\section{Pembahasan}

Berdasarkan hasil penelitian yang telah di uji secara statistik, maka berikut pembahasan tentang pengaruh opini audit, pergantian manajemen dan financial distress terhadap auditor switching.

\section{Pengaruh Opini Audit terhadap Auditor Switching}

Hasil pengujian pada variabel opini audit menunjukkan koefisien negatif sebesar -21,58 dengan tingkat signifikan sebesar 1 yang dapat dilihat dari Tabel 6 . Tingkat signifikan pada variabel opini audit lebih besar dari 0,05 (5\%). Berdasarkan hasil tersebut menunjukkan bahwa variabel opini audit tidak berpengaruh pada auditor switching. Hasil penelitian ini mendukung hasil penelitian sebelumnya yaitu Kurniaty dkk. (2014); Pawitri dan Yadnyana (2015) dan Heliodoro dkk. (2016). Penyebab variabel opini audit tidak berpengaruh terhadap auditor switching adalah perusahaan yang menjadi sampel sebagian besar mendapatkan opini wajar tanpa pengecualian dari kantor akuntan publik yang menjadi mitranya, sehingga jumlah perusahaan yang melakukan auditor switching tidak banyak. Pawitri dan Yadnyana (2015) juga mengungkapkan bahwa perusahaan yang menerima opini audit selain wajar tanpa pengecualian tidak selalu diikuti dengan pergantian 
kebijakan perusahaan untuk melakukan auditor switching; hal ini dikarenakan beberapa perusahaan akan lebih memilih untuk memperbaiki kesalahannya dibandingkan melakukan pergantian auditor.

\section{Pengaruh Pergantian Manajemen terhadap Auditor Switching}

Pada hasil penelitian yang dapat terlihat dari Tabel 6 , diperoleh tingkat signifikan variabel pergantian manajemen sebesar 0,463 lebih besar dari 0,05 (5\%). Hasil ini menujukan bahwa variabel pergantian manajemen tidak berpengaruh terhadap auditor switching, hal ini berarti sekalipun perusahaan melakukan pergantian manajemen, namun belum tentu terdapat kebijakan baru mengenai pergantian auditor. Dalam penelitian ini pergantian manajemen yang dilakukan oleh perusahaan yang dijadikan sampel, lebih erat kaitannya dengan evaluasi kinerja manajemen secara keseluruhan dan tidak selalu diikuti dengan pergantian auditor. Hasil penelitian ini didukung oleh Karina dkk. (2014), Kurniaty dkk. (2014) dan Augusty dan Wilopo (2017). Selama kebijakan yang dibuat oleh manajemen yang baru masih dapat disesuaikan dengan auditor yang ada, maka perusahaan tidak perlu melakukan auditor switching (Augusty \& Wilopo, 2017).

\section{Pengaruh Financial Distress terhadap Auditor Switching}

Hasil penelitian menunjukkan bahwa variabel financial distress memperoleh nilai signifikan sebesar 0,915 yang lebih besar dari 0,05 (5\%) yang dapat terlihat dari Tabel 6 . Hasil signifikan pada variabel financial distress yang lebih besar dari 0,05 menjelaskan bahwa financial distress tidak berpengaruh terhadap auditor switching. Financial distress tidak berpengaruh terhadap auditor switching karena auditor switching tidak selalu berhubungan dengan fee audit yang rendah, pergantian auditor yang dilakukan ketika perusahaan mengalami financial distress maka akan membebankan biaya ke perusahaan lebih besar lagi. Hasil penelitian ini didukung oleh penelitian sebelumnya yaitu Kurniaty dkk. (2014), Augusty dan Wilopo (2017) dan Safriliana dan Muawanah (2019). Ketika terjadi financial distress dalam sebuah perusahaan terkadang lebih baik perusahaan meningkatkan kondisi keuangannya dibandingkan melakukan pergantian auditor, karena biaya awal yang dikeluarkan oleh perusahaan untuk mencari auditor baru sangat tinggi, sehingga terkadang perusahaan akan mempertahankan auditor yang lama (Augusty \& Wilopo 2017).

\section{KESIMPULAN}

Penelitian ini bertujuan untuk menganalisis dan memberikan bukti pengaruh opini audit (audit opinion), pergantian manajemen (management change) dan kesulitan keuangan (financial distress) terhadap terjadinya auditor switching. Sampel yang digunakan dalam penelitian ini adalah perusahaan manufaktur sub sektor real estate dan property yang terdaftar di Bursa Efek Indonesia periode 2016 - 2018. Berdasarkan hasil penelitian Opini Audit, pergantian manajemen, financial distress tidak berpengaruh terhadap auditor switching pada perusahaan manufaktur sub sektor real estate dan property yang terdaftar di Bursa Efek Indonesia.

Keterbatasan dalam penelitian ini adalah penelitian ini hanya meneliti perusahaan manufaktur sub sektor real estate dan property yang terdaftar di BEI tahun 2016-2018, dan hanya menggunakan variabel opini audit, pergantian manajemen dan financial distress sebagai variabel yang mempengaruhi auditor switching. Peneliti selanjutnya disarankan untuk menggunakan seluruh perusahaan manufaktur yang terdaftar di Bursa Efek Indonesia, sehingga sampel untuk diteliti mengenai auditor switching akan lebih bertambah banyak, selain itu, peneliti selanjutnya sebaiknya menambah tahun pengamatan penelitian, sehingga akan lebih menggambarkan fenomena yang sedang terjadi dan mendapatkan hasil yang lebih maksimal. Peneliti selanjutnya juga disarankan untuk mempertimbangkan menambahkan variabel seperti reputasi KAP, audit fee, kepemilikan manajerial yang memungkinkan akan mempengaruhi perusahaan untuk melakukan auditor switching. 


\section{DAFTAR PUSTAKA}

Adha, A., \& Noch, M. (2017). Criterion of client's company, public accountant firm, financial distress, and company growth towards auditor switching. Trikonomika, 16(2), 81-87. https://doi.org/10.23969/trikonomika.v16i2.444

Alisa, I., Devi, I., \& Brillyandra, F. (2019). The effect of audit opinion, change of management, financial distress and size of a public accounting firm on auditor switching. Jurnal Akuntansi Trisakti, 6(1), 55-68. http://dx.doi.org/10.25105/jat.v6i1.4868

Augusty, E. V., \& Wilopo, R. (2019). Pengaruh pergantian manajemen, opini audit, dan kesulitan keuangan (financial distress) perusahaan terhadap pergantian auditor (auditor switching). The Indonesian Accounting Review, 7(2), 231-240. https://doi.org/10.14414/tiar.v7i2.950

Chadegani, A. A., Mohamed, Z. M., \& Jari, A. (2011). The determinant factors of auditor switch among companies listed on Tehran Stock Exchange. International Research Journal of Finance and Economics, 80(80), 158-168.

Ghozali, I. (2018). Aplikasi analisis multivariate dengan program IBM SPSS 25 (Edisi 9). Cetakan ke VIII. Semarang: Badan Penerbit Universitas Diponegoro.

Heliodoro, P. A., Carreira, F. A., \& Lopes, M. M. (2016). The change of auditor: The Portuguese case. Revista de Contabilidad, 19(2), 181-186. https://doi.org/10.1016/j.rcsar.2015.05.001

Hudaib, M., \& Cooke, T. E. (2005). The impact of managing director changes and financial distress on audit qualification and auditor switching. Journal of Business Finance \& Accounting, 32(910), 1703-1739. https://doi.org/10.1111/j.0306-686x.2005.00645.x

Karina, F. L., Kholmi, M., \& Harventy, G. (2017). Pengaruh opini going concern, pergantian manajemen dan ekspansi internal terhadap auditor switching secara voluntary. Jurnal Reviu Akuntansi dan Keuangan, 4(1), 555-562. https://doi.org/10.22219/jrak.v4i1.4928

Kholipah, S., \& Suryandari, D. (2019). Faktor-faktor yang mempengaruhi auditor switching pada perusahaan keuangan yang terdaftar di BEI Periode 2015-2017. Jurnal Akuntansi, 9(2), 8396.

Kurniaty, V., Hasan, H. A., \& Anisma, Y. (2014). Pengaruh pergantian manajemen, opini audit, financial distress, ukuran kap, dan ukuran perusahaan klien terhadap auditor switching pada perusahaan real estate dan properti di Bursa Efek Indonesia. Jurnal Online Mahasiswa (JOM) Bidang Ilmu Ekonomi, I( 2). Diakses dari https://jom.unri.ac.id/index.php/JOMFEKON/article/view/4598

Kusuma, H., \& Farida, D. (2019). Likelihood of auditor switching: Evidence for Indonesia. International Journal of Research in Business and Social Science, 8(2), 29-40. https://doi.org/10.20525/ijrbs.v8i2.192

Lin, Z. J., \& Liu, M. (2010). The determinants of auditor switching from the perspective of corporate governance in China. Advances in Accounting, 26(1), 117-127. https://doi.org/10.1016/j.adiac.2010.03.001

Manto, J. I., \& Wanda, D. L. (2018). Pengaruh financial distress, pergantian manajemen dan ukuran kap terhadap auditor switching. Media Riset Akuntansi, Auditing \& Informasi, 8(2), 205-224. https://doi.org/10.25105/mraai.v18i2.3212

Nazatul Faiza Syed Mustapha Nazri, S., Smith, M., \& Ismail, Z. (2012). Factors influencing auditor change: Evidence from Malaysia. Asian Review of Accounting, 20(3), 222-240. https://doi.org/10.1108/13217341211263274

Otoritas Jasa Keuangan. (2017). Peraturan Otoritas Jasa Keuangan Nomor 13 /Pojk.03/2017 tentang penggunaan jasa akuntan publik dan kantor akuntan publik dalam kegiatan jasa keuangan. Jakarta.

Pawitri, N., \& Yadnyana, K. (2015). Pengaruh audit delay, opini audit, reputasi auditor dan pergantian manajemen pada voluntary auditor switching. E-Jurnal Akuntansi, 10(1), 214-228. Retrieved from https://ojs.unud.ac.id/index.php/Akuntansi/article/view/9956

Peraturan Pemerintah Pemerintah Indonesia. (2015). Peraturan Pemerintah Republik Indonesia Nomor 20 Tahun 2015 tentang praktik akuntan publik. Jakarta. 
Permata Sari, G., \& Astika, I. (2018). Pengaruh opini going concern, financial distress dan kepemilikan institusional pada auditor switching. E-Jurnal Akuntansi, 23(2), 898-926. https://doi.org/10.24843/eja.2018.v23.i02.p04

Pusat Pembinaan Profesi Keuangan. (2020). Daftar Kantor Akuntan Publik (KAP) yang telah memperoleh izin dari Menteri Keuangan Per 2 Maret 2020. Diakses dari https://pppk.kemenkeu.go.id/in/post/daftar-kantor-akuntan-publik-aktif

Putra, I., \& Suryanawa, I. (2016). Pengaruh opini audit dan reputasi KAP pada auditor switching dengan financial distress sebagai variabel moderasi. E-Jurnal Akuntansi, 14(2), 1120-1149. Retrieved from https://ojs.unud.ac.id/index.php/Akuntansi/article/view/14991

Safriliana, R., \& Muawanah, S. (2019). Faktor yang memengaruhi auditor switching di Indonesia. Jurnal Akuntansi Aktual, 5(3), 234-240. https://doi.org/10.17977/um004v5i32019p234

Thahir Abdul Nasser, A., Abdul Wahid, E., Nazatul Faiza Syed Mustapha Nazri, S., \& Hudaib, M. (2006). Auditor-client relationship: the case of audit tenure and auditor switching in Malaysia. Managerial Auditing.Journal, 21(7), 724-737. https://doi.org/10.1108/02686900610680512

Wea, A. N. S., \& Murdiawati, D. (2015). Faktor-faktor yang mempengaruhi auditor switching secara voluntary pada perusahaan manufaktur. Jurnal Bisnis dan Ekonomi, 22(2), 154-170. 